\title{
Islamic Perspective on Creative Marine Ecotourism Development Policy in Kalanganyar Village Sedati Sidoarjo
}

\author{
M. Husni Tamrin ${ }^{1, \text { a }}$ \\ ${ }^{1}$ Department of Public Administration, Faculty of Social and Political Sciences, \\ Universitas Hang Tuah, Surabaya \\ Jln. Arief Rachman Hakim, No. 150 Sukolilo, Surabaya, 60111 \\ ${ }^{a}$ m.husnitamrin@hangtuah.ac.id
}

DOI: https://doi.org/10.22219/jes.v5i2.13330

Check for updates

\begin{tabular}{ll}
\hline \multirow{2}{*}{$\begin{array}{l}\text { Keywords: } \\
\text { Islamic values; } \\
\text { Tourism } \\
\text { development; } \\
\text { Tourism policy; }\end{array}$} & $\begin{array}{l}\text { ABSTRACT } \\
\text { Marine } \\
\text { ecotourism }\end{array}$ \\
$\begin{array}{l}\text { and also inhibitors of marine in an Islamic perspective. This study is qualitative, the data } \\
\text { collection obtained from direct interview with the staff officer and visitors } \\
\text { of Marine Tourism at Kalanganyar Village. This research using an } \\
\text { interaction model with three activities in data analysis namely: data } \\
\text { reduction, data presentation, and drawing a conclusion. The results of this } \\
\text { study found that Kalanganyar Village has a variety of tourism potential, } \\
\text { although there is still a lack of support from related agencies, such as the } \\
\text { existence of infrastructure and service as a tourist destination. However, } \\
\text { over all the potential of Marine Tourism at Kalanganyar Village have to } \\
\text { meet the objectives of shariah. }\end{array}$ \\
\hline
\end{tabular}

Article Info:

Submitted:

17/05/2020

Revised:

16/06/2020

Published:

25/08/2020

How to cite: Tamrin, M., H. (2020). Islamic Perspective on Creative Marine Ecotourism Development Policy in Kalanganyar Village Sedati Sidoarjo. Falah: Jurnal Ekonomi Syariah, 5(2), 70-83. https://doi.org/10.22219/jes.v5i2.13330 
Vol. 5 No. 2 (2020)

ISSN (print): 2502-3918 | ISSN (online): 2502-7824

\section{INTRODUCTION}

Indonesia is a country which has the largest archipelago in the world (Pradana, Pujiastuti \& Paramita, 2019; Laksono, Benyamin \& Mahmudiono, 2020). Indonesia is an archipelagic country that has a marine area that can be managed covering an area of 5.8 million $\mathrm{km}^{2}$ and has a lot of potential and a large variety of marine and fish resources, not to mention the commodity of fish cultivation that are increasingly developing in Indonesia through making fish ponds (Srivastav, \& Nishida, 2019; Rochwulaningsih, et. al., 2019; Fauzan \& Ahmad, 2019).

Developing the potential of an area is one of the objectives of regional spatial planning (Adhayanto, et. al., 2019). Therefore, the Province of East Java have to identify what potential can be the main focus, so that the achievement of regional development goals runs optimally, including in relation to the production of pond fish aquaculture (Ksatrya, 2019; Johanes \& Sri, 2019); Kurniawati, 2019). This potential needs to be developed into a tourism economy by utilizing the potential of fisheries to become marine ecotourism (Nurhayati, et. al., 2019; Abadi, et. al., 2020; Aswita, et. al., 2020) This is in accordance with the regulation of the Minister of Maritime Affairs and Fisheries of Republic Indonesia No. 34 Year 2014.

Tourism policies as regulations, rules, guidelines, direction, and development targets or the existence of a promotion and strategy that provides concepts in decision making individually or collectively, can directly realize the the long term development of tourism and at the same time the daily activities that take place in tourist sites (Goeldner \& Ritchie, 2006; Wardana, et. al., 2019).

The analyses of a National Policy as the Mission carried out by the Ministry of Culture and Tourism, are as follows: first, preserving the values of diversity and cultural wealth in order to strengthen the identity and character of a nation. Second, developing a competitive tourism industry, create sustainable destinations and implement responsible marketing. Third, developing cultural and tourism resources. Fourth, creating a government order that is responsive, transparent, and accountable (Wardana, et. al., 2019).

The concept of marine tourism is basically seen in the point of view on the uniqueness of nature, natural characteristics, and also the characteristics of art and culture and the characteristics of society as a strength possessed by each tourist area (Kellert, 2012; Holden, 2016). Rhormens, Pedrini \& Ghilardi-Lopes (2017) argues that marine ecotourism is a special market for people who understand and are aware of the environment, and are interested in observing the beauty of nature. Van Dyke \& Lamb (2020) describes marine ecotourism activities as an economic process that markets an interesting and relatively rare ecosystem. 
Muljadi (2009) revealed that a tourism village is a form of tourism products that includes elements of society with all the capabilities and limitations they have. Village tourism does not always have an impact on the economic level. The tourism village will certainly protect and preserve the state of the natural and socio-cultural environment, especially the community which is related to the elements of togetherness, kinship, and mutual cooperation. In other words, the preservation of nature and social culture will become an attraction for tourists who want to visit tourist attractions (Kurniawan \& Cahyono, 2020; Huong, et. al., 2020).

The village tourism concept is a product in tourism that must synergize the village community, either in its planning, development, management and service, so that later it can be felt directly by the people in the village tourism site (Van, 2020; Sari, et. al., 2020). Therefore, it will not cause a bad impact on the village, especially in Kalanganyar Village in Sidoarjo Regency where the tourist village is being developed. Kalanganyar Village is an example of a concrete step from the concept of a tourism village, where the focus is on preservation, education, and also the existence of the Village.

Kalanganyar Village owns both biological and non-biological potential as its maritime potential. This means that the geoeconomic situation in the fisheries sector in the Sidoarjo region is at a high productive level. The figure in the figure 1 shows that the productive geoeconomic situation indicates a dense population growth. Thus, this economic activity creates a center for developing highly potential fish cultivation, and Sidoarjo Regency has a very large potential in developing the fish cultivation sector compared to other regencies.

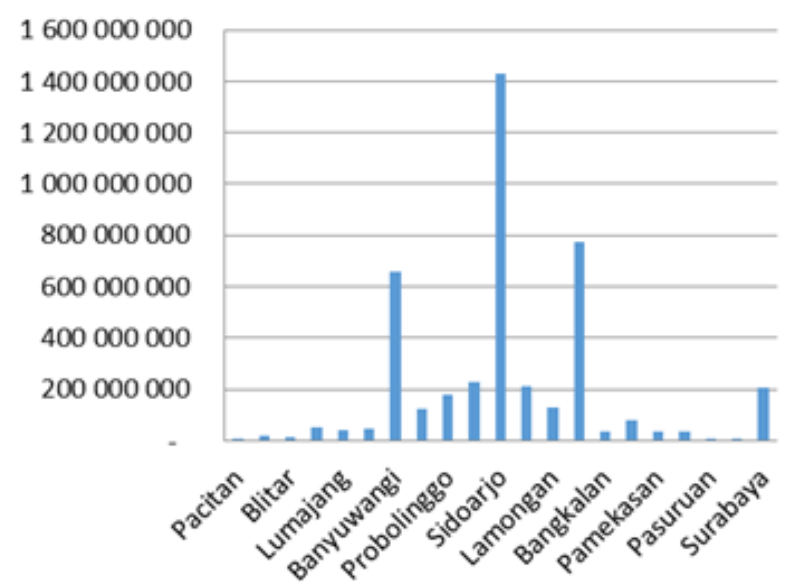

Figure 1. Comparison of Regency or City Pond Fish Aquaculture Production Level in East Java (in Indonesian Rupiah (IDR)).

Previous research attempted to analyse the need for the development of tourism industy. Katsitadze \& Natsvlishvili, 2020) stated that because of high economic performance of the tourism industry many countries increase their interest in tourism 
Vol. 5 No. 2 (2020)

ISSN (print): 2502-3918 | ISSN (online): 2502-7824

industry. Pakpahan (2019) stated the needs for better enforcement regarding tourist protection through clearer implementation instruction to increase thet level of tourism in Indonesia (Hamidi, Gharneh \& Khajeheian, 2020).

While, Alazaizeh, Ababneh \& Jamaliah (2020) argued that tourism stakeholders play critical roles in developing and planning sustainable heritage tourism. While Wardana, et. al., (2019) found that cultural tourism and ecotourism have positive and significant influence on sustainable tourism development efforts. It is also had a positive and significant influence on destination competitiveness. According to Van, (2020) to balance economic development and cultural preservation is a critical aspect of the negative effects of tourism on cultural preservation that can be prevented by applying the principles of sustainable development.

On the other hand, Hritz \& Cecil, (2019) found that sports tourism is perceived to bring significant benefits to a community hosting a sporting event. Accordingly, Deale (2020) stated that to increase the effectivity of tourism promotion students as researchers are also provided of the project were shared with community partners involved in in the local area, as a service learning project.

Nadalipour, et, al., (2019) found that an appropriate framework for tourism sustainable development for its sustainable competitiveness, requires considering economic, sociocultural and ecological dimensions on the one hand are very important factor. Nematpour \& Faraji (2019) stated that priority should be given to the negative influential factors, especially the environmental fields for reaching a sustainable system of tourism development. On the other hand, the availability of most accommodation units in the ecotourism segment become one of critical factor in the consumer's purchase decision process in ecotourism (Roseta, Sousa \& Roseta, 2020).

Further more, regenerative sustainability based on a holistic worldview and paradigm, integrating recent understandings from science and practice and also meet the need of customer is important to increase the sustainabilty of tourism destination (Gibbons, 2020; Harahsheh, Haddad \& Alshorman). In line with those view, Ghalia, et. al., (2019) found that an Institutional reform have an important rule to boost an economic benefit for countries that are highly dependent on tourism. Another factor also have to considered as Eid, El-Kassrawy \& Agag (2019) found that political (in)stability and destination image have a strong effect on tourist satisfaction and intention to recommend the tourism destination.

However, the previous research only focusing on the theory of eccotourism, its develpoment and sustainabilty factors but lack to attempt the impact of the values of Islamic perspective on ecotourism and its development. This study aims to explore a development policy and supporting factors, and also inhibitors of marine ecotourism in Kalanganyar Village, Kalanganyar Village in Sidoarjo Regency in an Islamic perspective. 


\section{RESEARCH METHOD}

This study is qualitative, to explore a development policy and supporting factors, and also inhibitors of marine ecotourism in Kalanganyar Village, Kalanganyar Village in Sidoarjo Regency in an Islamic perspective. The data collection obtained from direct interview with the staff officer and visitors of Marine Tourism at Kalanganyar Village. This research using an interaction model with three activities in data analysis namely: data reduction, data presentation, and drawing a conclusion (Sugiono, 2016).

This research uses descriptive qualitative by making direct observations, interviews, and documentation in the Village Kalanganyar Kec. Sedati Kab. Sidoarjo. The purpose of descriptive research is to make a systematic, factual, and accurate exploration of the phenomema occurring in the field, the characteristics, and relationships between the various symptoms to be examined. Based on these thoughts, direct observation methods, direct interviews, conducting in-depth interviews and study of documents, made in a descriptive manner are appropriate and assisting in the efforts to get facts related to the development of tourism destination strategies (Sugiono, 2016).

The data analysis technique used in this study is qualitative data analysis using an interaction model with three activities namely: data reduction, data presentation, and drawing a conclusion (Miles \& Huberman,1992).

Table 1. List of Informan of The Study

\begin{tabular}{clc}
\hline No & \multicolumn{1}{c}{ Name } & Rule \\
\hline 1 & Ibtadi Kadar Hernowo & $\begin{array}{c}\text { Head of Tourism Resources } \\
\text { Development Section }\end{array}$ \\
\hline 2 & Hariono & $\begin{array}{c}\text { Visitor of the marine ecotourism of } \\
\text { Kalanganyar Village }\end{array}$ \\
\hline 3 & Irham Tufiq & Head of Kalangnyar Village \\
\hline
\end{tabular}

\section{RESULT AND DISCUSSION}

From the results of the analysis on the interviews and observations made, tourism management and development policies in Kalanganyar Village, Sedati, Sidoarjo still have a gap between the infrastructure development in the form of tourism facilities and infrastructure with the cultural and artistic development. According to the Head of Tourism Resources Development Section Ibtadi Kadar Hernowo,

“...following the Sidoarjo Regency's vision and mission, the tourism sector is still so neglected that it is not a development priority for Sidoarjo Regency. Because they prioritize SMEs more than tourism."

In the development of a tourism, a clear concept and strategy is needed. Based on Law No.10 of 2009 concerning tourism contained in article 8 (eight), it is stated that a development plan in tourism can be regulated through a master plan in tourism 
Vol. 5 No. 2 (2020)

ISSN (print): 2502-3918 | ISSN (online): 2502-7824

development. This master plan consists of the basis of a national tourism master plan, a master plan in provincial tourism development, and a master plan in district/city tourism development. By always referring to the Sidoarjo Regency RIPPDA, then in developing tourism planning, processing, and development it is expected to be able to improve the quality of tourism by adjusting the direction of the policy based on regional development policy.

From the results of the discussion on the ecotourism policy of Kalanganyar Village, Sidoarjo Regency, there is an overlap in determining the direction of the policy. In fact that Kalangnyar Village is a very strategic area, so in the policy of developing marine ecotourism, it can show consistency in terms of future development policies. Apart from being the best and highest milkfish producer in Sidoarjo Regency, Kalanganyar Village has an underestimated potential. an example is the land that produces salt products in Kalanganyar Village. However, salt farmers are still considered underrated, although they have a great potential to increase the selling value and economic value in Kalanganyar Village.

In addition, there are various fishing ponds that provide various types of fish and facilities on the right side of the road to the estuary to the sea. There are many locations for fishing for those who like fishing or beginners in fishing. The cool and calm atmosphere with a lot of sea breeze is certainly an advantage for the marine ecotourism of Kalanganyar Village and for elements of the community who want to travel and enjoy family vacation time. In the Kalanganyar Village fishing ponds, there are also many spots for relaxing and eating together from the catch. Furthermore, the number of housewives who work as fishbone pullers so the fish can be immediately grilled on venue also adds a warm holiday atmosphere with the family. In line with the interview revealed by Mr. Hariono as a visitor who likes fishing in the marine ecotourism of Kalanganyar Village:

"... I went to Kalanganyar village for entertainment. Here, fishing and souvenirs are cheap. Not only that here it can directly pull out the fish bones, and the fish can be immediately grilled, the process is also very quick without having to wait for a long time. The place is also quite decent, and good weather for a vacation to relieve stress because of work.."

The phrase is very appropriate for consistency in marine ecotourism policy in Kalanganyar Village. Because it has fulfilled the quality of branding and the feasibility of tourism, as well as in improving the standard of living of the community and also increasing a more value in the Kalanganyar Village Sidoarjo Regency.

As for the potential focus of Kalanganyar Village, as a whole the village has been well designed in the form of superior tourism products that have high economic value. They can also increase income for the community in Kalanganyar Village. An interview with Mr. Irham Tufiq as Head of Kalangnyar Village revealed: 
“... for tourism potential, the fishing pond itself is already very crowded, but in the development process it is still planned, even though there are many SMEs that have been visited by the Sidoarjo tourism office, because there are many SMEs here. In addition, SMEs' achievement in Kalanganyar Village won the first place in Sidoarjo Regency, in the SMEs village competition ...".

The great potential of Kalanganyar Village as capital to attract tourists to visit Kalangnyar Village, Sidoarjo Regency, can be seen from the activities and conditions of the village, both environmental and aquaculture conditions. These conditions can be regulated and adjusted to tourism needs so that they will be beneficial. This is in accordance with the focus of the big concept, which is divided into two potentialsvillage potential and natural potential.

\section{The Potential Ecotourism of Kalanganyar village}

The Village Potential of Kalanganyar village is the best producer of milkfish in Sidoarjo Regency, and it has other underestimated potentials. One of the examples is the potential for salt land. Farmers who cultivate salt ponds are still considered underrated, although the profession turned out to have a considerable potential in increasing economic value. In the Kalanganyar Village area, infrastructure is also provided in the learning activities of milkfish processing from fishbone pulling to fish smoking and packaging, for visitors and SMEs who are interested in processing milkfish. The superior products of Kalanganyar Village are milkfish bone pulling, smoked milkfish processing, pressurecooked milkfish, or fishcake. Kalanganyar Village is also available with TPI (Fish Processing Site) complete with various types of fish. From the prominent potential of the village, it can be packaged in a superior tourism product that has high economic value, and can increase income for the environment and the community.

Natural potential is the superior potential in the form of fishing ponds and breeding ponds of around 3000 ha. The village also has a natural potential such as sunrise and sunset that can be seen directly when it is not cloudy or rainy. For tourists, they can enjoy community activities by observing the various activities of the fishermen and pond farmers. The results of an interview with Mr. Irham Taufiq as the Head of Kalangnyar Village revealed:

"... The natural potential of Kalanganyar village is actually very large. If the road to travel is adequate, but there are obstacles to the widening of the road that cannot be paved because the road is too narrow. This is because the Regional Office also does not allow it for certain reasons and policies ...".

The natural potential in the form of agriculture and landscape in Kalanganyar Village is focused as a superior tourism product. The facilities are rest areas. The planned outdoor facilities can later be enjoyed by tourists to fill holiday activities and spend time 
Vol. 5 No. 2 (2020)

ISSN (print): 2502-3918 | ISSN (online): 2502-7824

with family. Tourists can also see the panorama of nature and the vast green rice fields, and the manager of ecotourism will use vacant land to expand the tourist area.

From the discussion, it is found that the Sidoarjo Regency tourism office was very influential to support the potential of tourism as an area of marine ecotourism and land conservation for fishing ponds, and can support promotional activities and information to the public. This is in line with the view of Katsitadze \& Natsvlishvili, 2020) that because of high economic performance of the tourism industry many countries increase their interest in tourism industry. the needs for better enforcement regarding tourist protection through clearer implementation instruction to increase thet level of tourism in Indonesia (Pakpahan, 2019; Hamidi, Shams Gharneh \& Khajeheian, 2020).

In addition, the ecotourism policy of Kalanganyar Village should be able to cultivate aquaculture land as a marine ecotourism destination for the attractiveness of Kalanganyar Village so that later it can become a pilot village for other villages in Sidoarjo Regency. In line with this statement, Nadalipour, et, al., (2019) also argue that an appropriate framework for tourism sustainable development for its sustainable competitiveness, requires considering economic, sociocultural and ecological dimensions on the one hand are very important factor. the priority should be given to the negative influential factors, especially the environmental fields for reaching a sustainable system of tourism development (Nematpour \& Faraji, 2019). Furthermore, Roseta, Sousa \& Roseta, (2020) stated that the availability of most accommodation units in the ecotourism segment become one of critical factor in the consumer's purchase decision process in ecotourism.

On the other hand, local communities also play a full role as Human Resources to serve tourists visitation in marine ecotourism. As for the private sector as the holder of the right to manage the area, they play a role in regulating infrastructure facilities in the marine ecotourism area of Kalanganyar Village, especially for farmers who process ponds and members of the local community. These parties will later participate in carrying out marine ecotourism both the places and visitors visiting the marine ecotourism of Kalanganyar Village.

This is in line with Hritz \& Cecil, (2019) stated that sports tourism is perceived to bring significant benefits to a community hosting a sporting event. Accordingly, Deale (2020) stated that to increase the effectivity of tourism promotion students as researchers are also provided of the project were shared with community partners involved in in the local area, as a service learning project. Another factor also have to considered that political (in)stability and destination image have a strong effect on tourist satisfaction and intention to recommend the tourism destination (Eid, El-Kassrawy \& Agag, 2019). 


\section{An Islamic perspective on the development policy of marine ecotourism in Kalanganyar Village Sidoarjo}

Public policy is a complex pattern of various interdependent collective choices, including a decision of not taking any action, which is governed by a government agency or office (Dunn, 2003). In Sharia, the goal of public policy is to give birth to the economic benefit of the society. This benefit has two main dimensions which are the benefit dimension and the blessing dimension. The benefit dimension refers to economic benefits that are enjoyed by all levels of society equally and fairly. The blessing dimension, on the other hand, refers to the quality of economic development. The emergence of calm, serenity, and social security are parts of the indicators of economic blessing, in addition to the increase of morality and the quality of public obedience to the provisions of Allah (Anwar, 2011). This is the main vision of well-being, as Allah stated in QS. Quraisy[106]: 3-4, "Let them worship the Lord of this House, Who has fed them, [saving them] from hunger and made them safe, [saving them] from fear."

This is in line with Gibbons, (2020), Harahsheh, Haddad \& Alshorman; Ghalia, et. al., (2019) that regenerative sustainability based on a holistic worldview and paradigm, integrating recent understandings from science and practice and also meet the need of customer is important to increase the sustainabilty of tourism destination.

Therefore, if economic development merely increases income but gives birth to moral damage. This means something is wrong and needs to be fixed. Sharia-oriented public policies are general policies that give birth to the welfare of the people with the main pillar of meeting the objectives of sharia (maqashid syari'ah). To achieve this goal classical Muslim scientists and scholars such as Imam Al-Ghazali and Imam Asy-Syatibi, emphasized the importance of fulfilling the pillars of the maqashid syari'ah in all general policies that were born by leaders (ulil amri) or the Islamic government (Rahman, 2019).

As we all know, there are five elements of maqashid syariah in the Maqashid Pillars according to Imam Asy Syatibi. Those are religious protection (hifzu din), self protection (hifzun nafs), hereditary protection (hifzun nasl), protection of the reason (hifzul 'aql), and protection of property (hifzul maal). The whole design of public policy must not conflict with these five elements of maqashid, because if that happens, then the results or outputs of the policy will surely give birth to enormous economic disadvantages (Djamil, 2017).

First, religious protection (hifzu din) policies will provide space for the public to fulfill their religious obligations well. Therefore, if there is still a prohibition on praying during working hours, or restricting the right of citizens to fulfill the obligation of zakat, then it is contrary to this element of religious protection.

Then, secondly policies which are oriented towards religious protection will lead to social protection and social security (self protection). The primary needs of the 
community must be fulfilled. Therefore, the government will always think about not letting its citizens have to lose their lives just because of lack of money to buy food, or difficulty accessing health services.

Third, policies oriented to hereditary protection (hifzun nasl) means the government is always thinking about the fate of future generations. The government does not let future generations bear the negative consequences of current policies. Therefore, the government will minimize economic development policies that over-exploit natural resources, or leave future generations with a very heavy debt burden.

Meanwhile, the fourth, policies oriented to protection of the reason (hifzul 'aql) will give a reason for to governance that is always on the lookout for industries that can damage human reason and become a major source of crime, such as the liquor industry and drug abuse. Finally, policies based on protection of property (hifzul maal) will encourage the government to create equitable control of wealth, not to create an accumulation of assets in the hands of a few groups, or not to let the country's natural resources be controlled and monopolized by foreign interests.

The activities of tourism in an Islamic Perspective not only for the shake of happiness only, but also for the God worship (Hakim, \& Muslikhati, 2019; Rifa'i, 2019). Therefore the development of tourism destination have to develop an integrated concept which meet muslim tourist need (Rifa'i, 2018). This is in line with Alazaizeh, Ababneh \& Jamaliah (2020) argued that tourism stakeholders play critical roles in developing and planning sustainable heritage tourism. The cultural tourism and ecotourism also have positive and significant influence on sustainable tourism development efforts. It is also had a positive and significant influence on destination competitiveness (Wardana, et. al., 2019). Yet the balance of economic development and cultural preservation is a critical aspect of the negative effects of tourism on cultural preservation that can be prevented by applying the principles of sustainable development (Van, 2020).

\section{CONCLUSION}

Based on the findings, it is can be concluded that there are constraints in the construction of public facilities in Kalanganyar Village as follows: first, the limited allocation of funds and development. Second, the lack of facilities and infrastructure. Third, inadequate policies that specifically support the development of regional tourism in Kalanganyar Village as a marine ecotourism. There are two push-factors potential this village as a magnet for increasing tourist arrivals, which are the development of marine ecotourism, village potential and natural potential and also fishing and culinary ponds. However, over all the potential of Marine Tourism at Kalanganyar Village have to meet the objectives of shariah. 
However, this research has limited scope, where the analysis in this study is only on one destination of tourism. This study does not directly test the perception of tourist in wide population and sample. Future studies are expected to be able to study is on variatif destination of tourism and also expected to test the perception of tourist in wide population and sample.

\section{REFERENCES}

Abadi, T. W., Balahmar, A. R. U., \& Choiriyah, I. U. (2020). The Nexus of Local Government Involvement and Marine Sustainable Ecotourism Development: Mediating Role of Supply Chain Management. International Journal of Supply Chain Management, 9(3), 642-648. Retrieved from https://www.researchgate.net/profile/Totok_Abadi/publication/342869759 The Nexus_of_Local_Government_Involvement_and_Marine_Sustainable_Ecotouri sm_Development_Mediating_Role_of_Supply_Chain_Management

Adhayanto, O., Sutikno, A., Irman, I., \& Nurhasanah, N. (2019, November). The Archipelago Regional Government Policy Reformulation in Indonesia. In ASEAN/Asian Academic Society International Conference Proceeding Series (pp. 481-487). Retrieved from http://aasic.org/proc/aasic/article/view/520

AJ, Muljadi. (2009). Kepariwisataan dan Perjalanan, Jakarta: PT RajaGrafindo Persada.

Alazaizeh, M. M., Ababneh, A., \& Jamaliah, M. M. (2020). Preservation vs. use: understanding tourism stakeholders' value perceptions toward Petra Archaeological Park. Journal of Tourism and Cultural Change, 18(3), 252-266. https://doi.org/10.1080/14766825.2019.1628243

Anwar, M. Z. (2011). Formalisasi Syariât Islam di Indonesia: Pendekatan Pluralisme Politik dalam Kebijakan Publik. Millah: Jurnal Studi Agama, 10(2), 191-212. https://doi.org/10.20885/millah.vol10.iss2.art1

Aswita, D., Suryadarma, I. G. P., Suyanto, S., \& Herawan, T. (2020). The Natural Resources Potency Of Marine Ecotourism As An Environmental Education Source. GeoJournal of Tourism and Geosites, 31(3), 996-1003. DOI.10.30892/gtg.3311331100--55333

Burkart, A. J., \& Medlik, S. (1981). Tourism: past, present and future., (Ed. 2). London: William Heinemann Ltd.

Deale, C. S. (2020). Students as Researchers: Learning about Tourists of the Future. Journal of Hospitality \& Tourism Education, 32(1), 32-42. https://doi.org/10.1080/10963758.2019.1654888

Djamil, F. (2017). Kebijakan Publik dan Keadilan Sosial dalam Perspektif al-Dawudi. Jakarta: Cakrawala Budaya.

Dunn, W. N. 2003. Analisis Kebijakan Publik. Yogyakarta: Gadjah Mada University Press.

Eid, R., El-Kassrawy, Y. A., \& Agag, G. (2019). Integrating destination attributes, political (in) stability, destination image, tourist satisfaction, and intention to recommend: A study of UAE. Journal of Hospitality \& Tourism Research, 43(6), 839-866. https://doi.org/10.1177/1096348019837750 
Vol. 5 No. 2 (2020)

ISSN (print): 2502-3918 | ISSN (online): 2502-7824

Fauzan, K. A., \& Ahmad, M. Z. (2019). Maritime border security and challenges for Indonesia. Malaysian Journal of Society and Space, 15(2), 155-165. https://doi.org/10.17576/geo-2019-1502-12

Ghalia, T., Fidrmuc, J., Samargandi, N., \& Sohag, K. (2019). Institutional quality, political risk and tourism. Tourism Management Perspectives, 32(1), 100576100595. https://doi.org/10.1016/j.tmp.2019.100576

Gibbons, L. V. (2020). Regenerative-The New Sustainable?. Sustainability, 12(13), 5483-5555. https://doi.org/10.3390/su12135483

Goeldner, Charles A. and J.R. Brent Ritchie, (2006). Tourism: Principles, Practices, Philosophies. $10^{\text {th }}$ ed., New York: Wiley.

Hakim, R. \& Muslikhati. (2019). A Review on Halal Tourism: an Analysis on the Parameters. Jurnal Ilmiah Ekonomi Islam, (5)3, 166-172. http://dx.doi.org/10.29040/jiei.v5i3.555

Hamidi, F., Shams Gharneh, N., \& Khajeheian, D. (2020). A Conceptual Framework for Value Co-Creation in Service Enterprises (Case of Tourism Agencies). Sustainability, 12(1), 213-224. https://doi.org/10.3390/su12010213

Harahsheh, S., Haddad, R., \& Alshorman, M. (2019). Implications of marketing Jordan as a Halal tourism destination. Journal of Islamic Marketing. 11(1), 97-116. https://doi.org/10.1108/JIMA-02-2018-0036

Holden, A. (2016). Environment and tourism. Routledge.

Hritz, N., \& Cecil, A. (2019). Small business owner's perception of the value and impacts of sport tourism on a destination. Journal of Convention \& Event Tourism, Routledge, 20(3), 224-240. https://doi.org/10.1080/15470148.2019.1635547

Huong, L. H., Thuy, B. L., \& Phuong Linh, N. T. (2020). Promoting Participation in Local Natural Resource Management through Ecological Cultural Tourism: Case Study in Vam Nao Reservoir Area, An Giang Province, Vietnam. Journal of Asian and African Studies, 55(6), 863-879. https://doi.org/10.1177/0021909620935426

Johanes, H., \& Sri, R. (2019). Development Strategy Of Mini-Scale Shrimp Farming On Plastic Pond (Busmetik) In Gemilang Minajaya Fish Farming Group Of Tegal City. Russian Journal of Agricultural and Socio-Economic Sciences, 87(3), 2436. Retrieved from https://cyberleninka.ru/article/n/development-strategy-ofmini-scale-shrimp-farming-on-plastic-pond-busmetik-in-gemilang-minajayafish-farming-group-of-tegal-city

Katsitadze, N., \& Natsvlishvili, I. (2020). The Role of State Regulation and Policy in Tourism Development: The Case of Georgia. Eurasian Economic Perspectives, 13(1), 419-434. Retrieved from https://link.springer.com/chapter/10.1007/978-3030-40375-1_28

Kellert, S. R. (2012). Building for life: Designing and understanding the human-nature connection. New York: Island press.

Ksatrya, S. P. (2019). Development of maritime logistics system to support marine and fisheries integrated centres in small island and boundary areas (Doctoral dissertation, University of Essex). Retrieved from http://repository.essex.ac.uk/26328/ 
Kurniawan, M. U., \& Cahyono, A. E. (2020, May). The community empowerment program based on local potential through tourism village. In IOP Conference Series: Earth and Environmental Science, 485(1), 12089-12097. IOP Publishing. https://10.1088/1755-1315/485/1/012089

Kurniawati, V. R. (2019). Sustainable development of fishing operations: a case study focusing on small vessels in Palabuhanratu, Indonesia (Doctoral dissertation, Newcastle University). Retrieved from https://theses.ncl.ac.uk/jspui/handle/10443/4630

Laksono, A. D., Benyamin, B., \& Mahmudiono, T. (2020). Disparity in the Hospitals Utilization among Regions in Indonesia. Health Economics \& Outcomes Research. 1(1), 1-12 https://10.21203/rs.3.rs-18070/v1

Miles, M, B., \& Huberman, A, M. (1992). Qualitative Data Analysis. California: Beverly Hills: Sage Publication Inc.

Nadalipour, Z., Khoshkhoo, M. H. I., \& Eftekhari, A. R. (2019). An integrated model of destination sustainable competitiveness. Competitiveness Review: An International Business Journal. 29(4), 314-335. https://doi.org/10.1108/CR-12$\underline{2017-0086}$

Nematpour, M., \& Faraji, A. (2019). Structural analysis of the tourism impacts in the form of future study in developing countries (Case Study: Iran). Journal of Tourism Futures. 5(3), 259-282. https://doi.org/10.1108/JTF-05-2018-0028

Nurhayati, A., Aisah, I., \& Supriatna, A. K. (2019). Model Development of A Synergistic Sustainable Marine Ecotourism-A Case Study in Pangandaran Region, West Java Province, Indonesia. Sustainability, 11(12), 3418-3432. https://doi.org/10.3390/su11123418

Nyoman S. P., (1986). Ilmu Pariwisata: Sebuah Pengantar Perdana. Jakarta: Pradnya Paramita.

Pakpahan, N. H. (2019). Tourist Legal Protection Through Manado's Regional Regulation to Increase Tourism Level in Manado. Journal of International Conference Proceedings, 2(2), 196-203. https://doi.org/10.32535/jicp.v2i2.619

Pradana, A., Pujiastuti, I., \& Paramita, P. P. (2019, November). Regionalization of Agricultural Based Leading Sectors and Food Security in Indonesia. In IOP Conference Series: Earth and Environmental Science, 338(1), 12015-12021. https://10.1088/1755-1315/338/1/012015

Rahman, H. Y. (2019). Kebijakan Pemerintah Terhadap Belt And Road Initiative (BRI) Dalam Paradigma Ekonomi Syariah. Al-Amwal: Jurnal Ekonomi dan Perbankan Syari'ah, 11(2), 173-190. https://doi.org/10.24235/amwal.v11i2.4537

Rifa'i, M. N. (2018). Promosi Makanan Halal di Kota Taipei, Taiwan. Falah: Jurnal Ekonomi Syariah, 3(1), 111-121. https://doi.org/10.22219/jes.v3i1.6515

Rifa'i, M. N. (2019). Integrasi Pariwisata Halal di Kota Malang. Falah: Jurnal Ekonomi Syariah, 4(2), 194-201. https://doi.org/10.22219/jes.v4i2.9876

Rochwulaningsih, Y., Sulistiyono, S. T., Masruroh, N. N., \& Maulany, N. N. (2019). Marine policy basis of Indonesia as a maritime state: The importance of integrated economy. Marine Policy, 108(1), 103602-103609. https://doi.org/10.1016/j.marpol.2019.103602 
Vol. 5 No. 2 (2020)

ISSN (print): 2502-3918 | ISSN (online): 2502-7824

Rhormens, M. S., Pedrini, A. D. G., \& Ghilardi-Lopes, N. P. (2017). Implementation feasibility of a marine ecotourism product on the reef environments of the marine protected areas of Tinharé and Boipeba Islands (Cairu, Bahia, Brazil). Ocean \& coastal management, 139(1), 1-11. https://doi.org/10.1016/j.ocecoaman.2017.01.022

Roseta, P., Sousa, B. B., \& Roseta, L. (2020). Determiners in the Consumer's Purchase Decision Process in Ecotourism Contexts: A Portuguese Case Study. Geosciences, 10(6), 224-244. https://doi.org/10.3390/geosciences10060224

Sari, S. R., Hilmy, M. F., Hendro, E. P., \& Iswanto, D. (2020). Maintain Sustainability of Historic Village as Tourism Village. The Case of Bustaman Village in Semarang, Indonesia. Aestimum, 79-98. Retrieved from https://www.rivistadistoriadelleducazione.it/index.php/ceset/article/download/82 $\underline{84 / 8478}$

Srivastav, A., \& Nishida. (2019). The Science and Impact of Climate Change. London: Springer.

Sugiono, S. (2016). Metode Penelitian Kuantitatif, Kualitatif, dan R \& D. Bandung: Alfabeta.

Van Dyke, F., \& Lamb, R. L. (2020). Conservation Economics and Sustainable Development. In Conservation Biology (pp. 449-487). Springer, Cham. https://doi.org/10.1007/978-3-030-39534-6_14

Van, V. H. (2020). Linking Cultural Heritage with Cultural Tourism Development: A Way to Develop Tourism Sustainably. Preprints 2020, 2020080546. https://10.20944/preprints202008.0546.v1

Wardana, I. M., Sukaatmadja, I. P. G., Yasa, N. N. K., \& Astawa, I. P. (2019). Cultural Tourism and Ecotourism Empowerment in the Sustainable Tourism Development and Destination Competitiveness Enhancement. Journal of Environmental $\begin{array}{llll}\text { Management } \quad \text { Tourism, } & \text { 753-762. }\end{array}$ https://doi.org/10.14505//jemt.v10.4(36).06

Xu, F. (2020). A Resource Market and Product Analysis for Marine Tourism Development. Journal of Coastal Research, 107(SI), 93-96. https://doi.org/10.2112/JCR-SI107-024.1 